\title{
多孔性配位高分子のナノ空間への高選択的ゲスト吸着 \\ Highly Selective Guest Adsorption in the Nanospace of Porous Coordination Polymers
}

\author{
科学技術振興機構 ERATO 北川統合細孔プロジェクト＼cjkstart松田＼cjkstart亮太郎* \\ ERATO Kitagawa Integrated Pores Project, Japan Science and Technology Agency \\ Ryotaro Matsuda* \\ Received February 14, 2011; E-mail: ryotaro.matsuda@kip.jst.go.jp
}

\begin{abstract}
Nanoporous materials are ubiquitous and indispensable in daily life as adsorbents. The discovery of a new porous compound having unique properties based on intrinsic nano-sized space and surface functionalities is scientifically and technologically important. Recently, porous coordination polymers (PCPs) or metal organic frameworks (MOFs) have been extensively studied because they can provide variety of nano-sized space in their stable frameworks by taking advantage of the features of "metal complex". Now, many unusual porous functions have been achieved in this class of compounds, which have not been found in the traditional materials. In this accounts, we focus on the synthesis and functionalization of porous coordination polymers and their unusual selective sorption properties. Here, the following topics have been reported; 1) highly controlled acetylene accommodation in one dimensional channel, 2) a molecular gate exhibiting a locking / unlocking system in the nano-channel, 3) selective sorption of $\mathrm{O}_{2}$ and NO in a TCNQ based porous coordination polymer utilizing charge transfer interaction, and 4) on-demand photochemical guest trapping and conversion by a light-responsive porous coordination polymer.
\end{abstract}

\section{1. はじめに}

いうまでもなく気体は形もなく、異なる分子も自由に 混ざり合い、多くのものは無色透明で取り扱うのが難し い。しかしながら、標準環境温度・圧力において気体状 態で存在する分子（以下、気体分子）は、我々の身の回 りの環境・エネルギー、物質合成、生命現象に至るま で様々なところで直接的、間接的に重要な役割を果た している。そのため、気体分子を自在に分離、貯蔵、変 換するためのテクノロジーや物質の開発は昔から求めら れているが、持続可能な社会の実現など現代の社会的要 請から、今さらにその重要性を増している。多くの気体 分子がサブナノメートルオーダーの大きさであるため、 それらを包摂あるいは吸着することが可能な、 $2 \mathrm{~nm}$ 以 下のナノ空間を有するミクロ孔物質は ${ }^{1)}$ 、気体分子の 自在制御を行うための中心的役割を果たす物質である ${ }^{2}$, 3)。活性炭やゼオライトなどの多孔性無機固体は、古く

連絡先著者名: 松田亮太郎

連絡先: 600-8815 京都市下京区中堂寺粟田町 93

京都リサーチパーク 3 号館 405

科学技術振興機構 ERATO 北川統合細孔プロジェクト

Tel: 075-322-4711 Fax: 075-325-3572

Corresponding Author: Ryotaro Matsuda

Address: Kyoto Research Park Bldg\#3-405, 93 Chudoji-Awatacho, Shimogyoku, Kyoto 600-8815, Japan

Keywords:coordination polymer, metal organic framework, selective adsorption, light stimulation, charge transfer
から重要なミクロ孔物質として使われているが、一方 で、近年新しいミクロ孔物質の開発もめざましく、なか でも金属イオンと有機配位子で作られる多孔性配位高 分子 (Porous Coordination Polymers / PCPs あるいは Metal Organic Frameworks / MOFs) はその構造多様性と特異な 細孔特性から非常に注目されている ${ }^{4-31) 。 こ れ ら の ミ ク ~}$ 口孔物質を用い、気体分子を選択的に識別して吸着・分 離を行うためには、熱力学的特性と速度論的特性の両方 を考える必要がある。両者は細孔表面と吸着質との相互 作用と、気体分子および細孔の形状や大きさに関連する。 たとえば、細孔サイズが分子サイズと同じくらい小さく なると、上下左右の細孔壁からのポテンシャルが重なり 合い、非常に深い吸着ポテンシャルを形成し、吸着エネ ルギーは大きくなる ${ }^{32,33)}$ 。また、それにともない拡散速 度は小さくなり、分子より小さなパスが存在するまでに なると吸着が困難になり、分子ふるい効果が期待できる。 すなわち、特異な選択的吸着を実現するには、ゲスト分 子の化学的・物理的・幾何学的特徵を詳細に捉え、それ らの違いを認識できるミクロ孔物質をデザインし合成す ることが要である。代表的な気体分子に関して、沸点と 分子サイズ (Kinetic diameter) $)^{3)}$ のれぞれを横軸と縦軸 にプロットした (Fig.1)。気体が凝縮する温度は気体分子 間の相互作用の大きさに依るので、沸点は分子間相互作 用の大きさの指標となる。単純な物理吸着を考えた場合、 プロットした点が離れている分子同士は性質が大きく異 


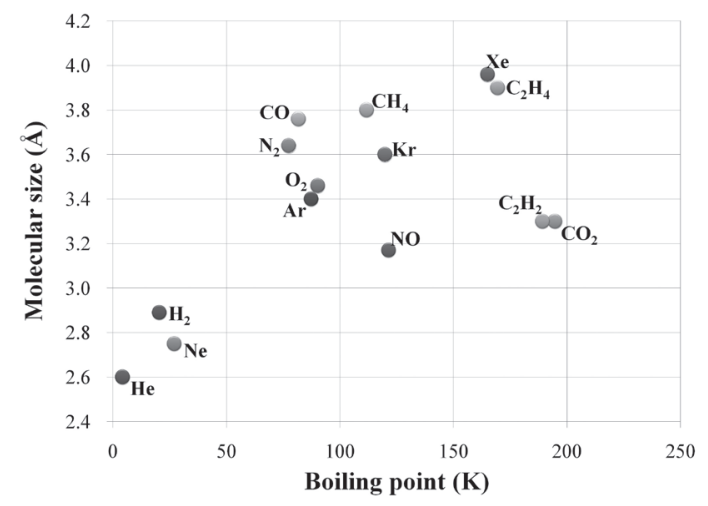

Fig. 1 Molecular sizes (kinetic diameter) and standard boiling points of small molecules.

なっており、そ扎らを分離することは容易であるが、プ ロットした点が近接している分子同士は、分子の特性が 非常に似通っており、ミクロ孔物質で片方の分子を選択 的に吸着させることは通常難しいと考えられる。一方、 多孔性配位高分子は有機配位子と金属イオンを組み合わ せて合成することから、多様な構造を設計し、構造体を 組みあげることが可能であり、有機配位子や金属イオン の配位環境を変化させることにより、細孔の表面の性質、 細孔のサイズや形状、フレームワークの動的な特性を 様々に変化させることも可能である。そのため、細孔の サイズや細孔表面の物理的・化学的性質をさまざまに変 化させて構造体を組みあげ、通常では難しい選択的な吸 着特性を実現できると期待される。以上の観点から、本 論文では多孔性配位高分子を用い、如何にして性質の似 通った気体分子に対し選択的な吸着を実現できるかとい うことに焦点を置き、新しい多孔性配位高分子の合成か ら、それらが有するナノ空間への分子吸着特性までを論 じたい。

\section{2. アセチレンの高選択吸着と高濃縮}

多孔性配位高分子が他の物質と比較して特筆すべきこ との1つは、フレームワークに用いる有機分子に付与さ れている（もしくは意図的に付与した）機能を細孔に直 接反映させられることである。たとえば、有機分子にヒ ドロキシル基を導入し細孔表面改質して親水性ゲスト分 子の吸着力を上げたり、有機分子に不斉点を導入し、光 学活性なゲスト分子に対して片方の光学異性体を選択的 に取り込んだり ${ }^{5)}$ 、また不斉触媒反応を行なう反応場と

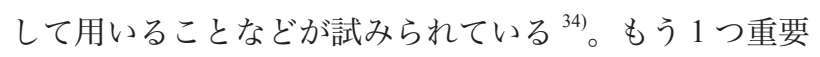
な点は、多孔性配位高分子のほとんどは結晶性固体であ り、有機分子中の官能基も規則的かつ均一に細孔表面に 存在しているということである。もし吸着したゲスト分 子と細孔表面の官能基との立体的な配置がうまく合致す れば、細孔空間の立体的な効果と官能基の化学的な効果 が相乗的にゲスト分子に対して影響を及ぼし、強い束縛
状況下でゲスト分子を捕らえられると期待できる。

著者らが合成した Coordination Pillared Layer Structures (CPL-0) シリーズと呼ぶ一連の化合物は $\left[\mathrm{Cu}_{2}(\mathrm{pzdc})_{2} \mathrm{~L}\right]$, $($ pzdc $=$ pyrazine-2,3-dicarboxylate, $L=$ ピラー配位子 $) の$ 一般組成を有する多孔性配位高分子である ${ }^{35-45)}$ 。CPL-0 シリーズは銅 (II) と pzdcによってレイヤー構造を形成 し、ピラー配位子Lによってそれを連結した構造を有 している。また、ピラー配位子は 1 軸方向に関してピ ラー同士の間隔が非常に近接しているため、レイヤー とピラーで区切られる細孔は 1 次元の空間となってい る。また、CPL-0 シリーズはピラー配位子をピラジンや 4,4'-ビピリジン (bpy) など様々に変化させて細孔の大き さを調節できる特徵を有している (Fig. 2)。これまでに、 CPL-0 シリーズの中で $4 \times 6 \AA$ と最も小さな入りロサイズ の 1 次元細孔を有する CPL-1 を用いて、細孔中に酸素 分子を 1 次元に並べることが実現されている。また、ラ マン分光測定により、この細孔中の酸素分子は固体酸素 に約 $2 \mathrm{GPa}$ という巨大圧力をかけたのと同程度の圧力を

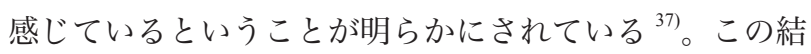
果から CPL-1 の小さな細孔は 2 原子分子程度の大きさ のゲスト分子に対して特別な相互作用がなくても、非常 に強い束縛効果を示すことがわかった ${ }^{46}$ 。そこで次に分 散力以外の水素結合など指向性の相互作用が㗢くゲスト 分子をこの小さな細孔へ吸着させた場合、細孔の持って いる束縛効果に加えて、付加的な相互作用が相乗的に働 き、特異的な吸着を実現できのではないかと考えた。

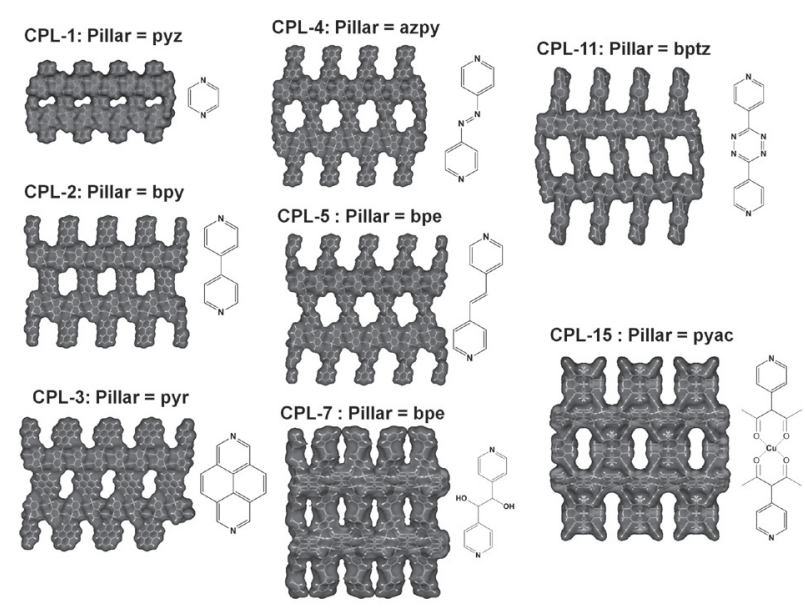

Fig. 2 Crystal structures of CPL-0 porous coordination polymers.

CPL-1 の合成時の細孔内をみると、合成溶媒である水 分子が細孔 1 つあたり 2 分子取り込まれている。その水 分子は細孔表面に露出している配位子由来の塩基性の酸 素原子と水素結合しており、チャンネル方向に水分子の 1 次元鎖が形成されている (Fig. 3)。著者らはこの酸素原 子に注目し、ここを機能性部位として働かせることを考 え、この酸素原子と相互作用できるゲスト分子の検討を 行った結果、アセチレンが候補にのぼった。アセチレン は 4 原子分子であるがサイズは二酸化炭素とほぼ同じで 


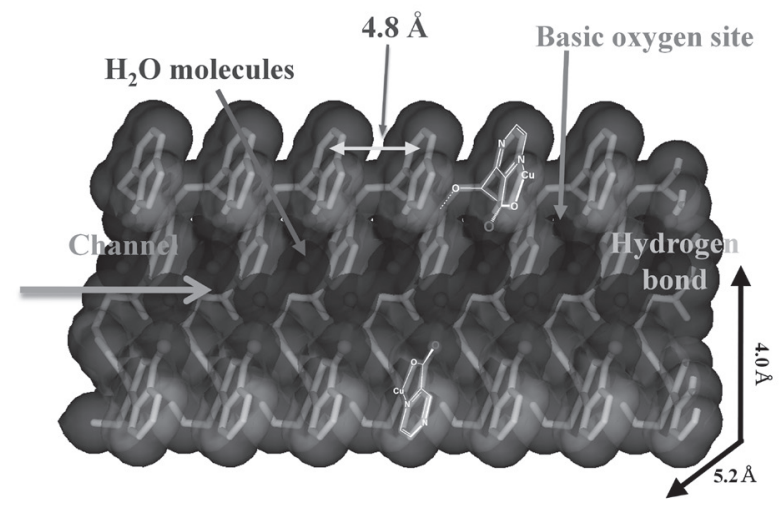

Fig. 3 Channel structure of as-synthesized CPL-1.

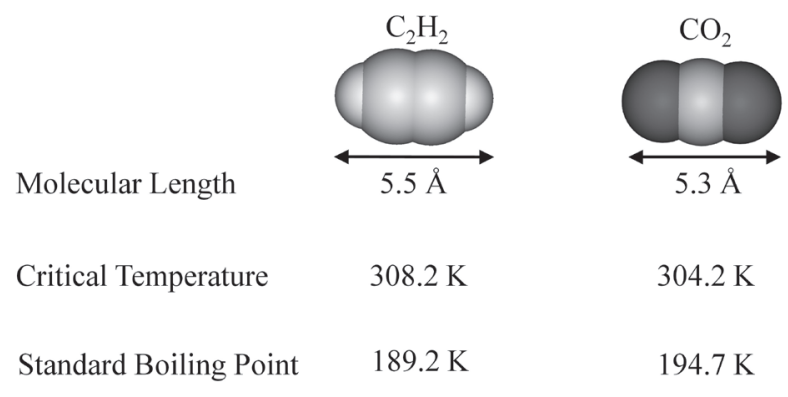

Fig. 4 Comparison for size and physical properties between acetylene and carbon dioxide.

あり、大きさとしては CPL-1 の細孔へ吸着するのに適 している。またアセチレンは、両末端に比較的酸性な水 素原子を有しており、水分子と同様に細孔壁の塩基性の 酸素原子と水素結合を形成することが期待された。その 一方で、アセチレンは非常に反応活性な分子で、たった 2 気圧の加圧で分解爆発の危険性のある気体であること

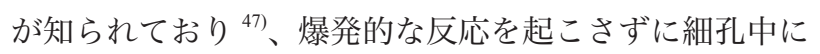
規則正しく配列させ、濃縮可能かどうかという点でも興 味が持たれた。

二酸化炭素はアセチレンとサイズおよび沸点などの物 理化学的性質が酷似しているため (Fig. 4)、通常の吸着 剤では同様の吸着挙動を示す。そこで二酸化炭素とア セチレンの吸着挙動を比較すれば、CPL-1 の細孔壁に露 出する酸素原子の効果を検討できると考えた。Fig. 5 は 270K における CPL-1 へのアセチレンと二酸化炭素の吸 着等温線である。二酸化炭素は $5 \mathrm{kPa}$ までの低圧領域で ほとんど吸着しないが、アセチレンは低圧で急激に吸着

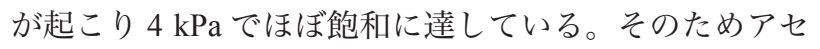
チレンと二酸化炭素の吸着量の差は最大で 26 倍量にも なることがわかった。さらに等量吸着熱もアセチレンの 方が $10 \mathrm{~kJ} / \mathrm{mol}$ も大きく、吸着によるアセチレンの安定 化が顕著に示される結果であった。また、吸着量が細孔 $1 つ に$ 対して1分子であることは注目すべき点である。 これは吸着されたアセチレン分子が 1 次元細孔中で細孔 の規則性と整合性のとれた構造体を形成していることを 示唆している。近年 X線回折または中性子線回折実験

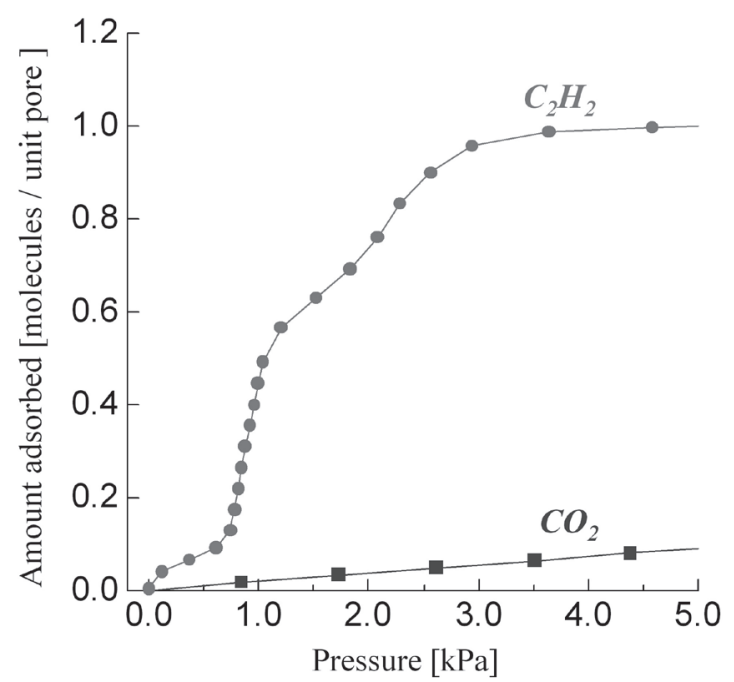

Fig. 5 Adsorption isotherms of acetylene and carbon dioxide on CPL-1 at $270 \mathrm{~K}$.

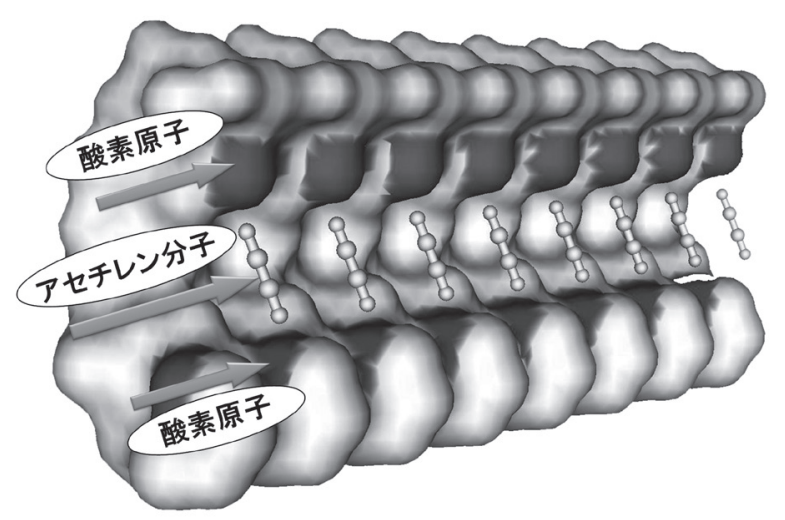

Fig. 6 Crystal structure of trapped acetylenes in CPL-1.

のその場測定によりゲスト分子を直接観察することは、 吸着のメカニズムを明らかにする上で非常に有用な手段 となっている ${ }^{37-42,48-60)}$ 。そこでこのアセチレンの吸着現 象を構造的に解明することを目指し、放射光を用いた粉 末 X 線回折測定 ${ }^{61)}$ と MEM (Maximum Entropy Method) / Rietveld 法 ${ }^{62,63)}$ と呼ばれる解析手法を用いて、吸着前後 における細孔構造を明らかにした。吸着前の構造では水 分子が取り除かれ、空孔には何も存在していないが、吸 着後はアセチレンが細孔の中心に 1 取り込まれている ことがわかった。興味深いことに、棒状のアセチレン分 子はその向きを細孔壁の酸素原子へ向け、あたかも酸素 原子に抱えられているような構造であった (Fig. 6)。構 造解析の結果を用いて、MEMによる細孔の電子密度分 布を計算してみると、アセチレンの水素原子と細孔の酸 素原子の間に $0.21 \mathrm{e} / \AA^{3}$ の電子密度が観測され、細孔壁 とゲスト分子の間の電子的な相互作用が直接的に確認さ 水た。

また細孔内部の空孔では、アセチレン分子は極めて高 密度に存在し、通常の気相では起こりえない状態である こともわかった。CPL-1の細孔1つあたりの細孔容積は 
$99.7 \AA$ であり、その空孔にアセチレンが 1つ入っている ので、その空間充填密度は $0.44 \mathrm{~g} / \mathrm{cm}^{3}$ となる。一方、2 気圧に加圧したときのアセチレンの気体密度は $0.0021 \mathrm{~g}$ / $\mathrm{cm}^{3}$ である。つまり、CPL-1の細孔内部のアセチレン 密度は爆発限界の約 200 倍もの密度に濃縮されていると いう驚異的な状態であることがわかった。これは、アセ チレンが細孔中で細孔壁の酸素原子によって強く束縛さ れ、決まった配向で整然と吸着されるため、爆発的な反 応が起こらないものと考えている ${ }^{40)}$ 。

\section{3. 水素結合でゲートを開閉する多孔性配位高分子}

1990 年代から 2000 年代初頭までの多孔性配位高分子 の研究は、堅牢な骨格を有しゼオライト様の多孔性機能 を発現する物質を設計・合成することが目標であった ${ }^{6}$, 34, 35, 48, 49, 54, 64-93)。しかしその後、ゲスト分子の吸脱着など 物理的・化学的刺激に応答して結晶構造を変化させる動 的構造体を作成できることがわかってきた ${ }^{21,36,39,41,51,60,}$ 65, 74, 91, 94-116)。これらの構造変換には、(1) 配位結合の開裂・

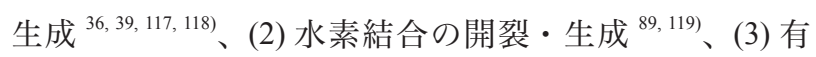
機分子の回転や配向の変化 ${ }^{56,57,59,60,111,114,120)}$ を伴うもの が多く見出されている。これらは多孔性配位高分子が無 機と有機の複合物質であること、すなわち錯体であるこ とに起因している。我々は動的な構造変換を有機配位子 の様々な修飾によって制御し、ゲスト吸着特性を変化さ せることを試みてきた。本項では、そのうち水素結合で 細孔のゲートを開閉可能な多孔性配位高分子について述 べる (Fig. 7) ${ }^{121)}$

\section{Molecular Gate with Lock System}

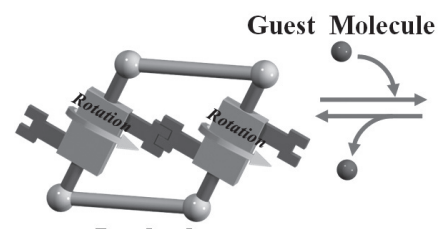

Locked

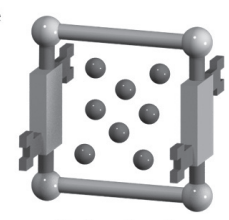

Unlocked

Fig. 7 Schematic representation of molecular gate with lock system in CPL-201.

著者らはまず、新しい配位子 $\mathbf{L}=2,5$ - ビス (2-ヒドロ キシエトキシ )-1,4-ビス (4- ピリジル ) ベンゼンを合成 した (Fig. 8)。この配位子は中心のベンゼン環の 1,4 位 に配位サイトとして 2つの 4- ピリジル基がついており、 中心のベンゼン環が回転できるようになっている。また、 2つの2-ヒドロキシエトキシ基は水素結合性のゲスト 分子と相互作用できると共に、ベンゼン環の回転運動の しやすさを変化させるアンカーとしての役割を果たすも のと期待した。この配位子 $\mathrm{L}$ と $\mathrm{H}_{2} \mathrm{pzdc}$ および $\mathrm{Cd}\left(\mathrm{NO}_{3}\right)_{2}$ をエタノール / 水の混合溶液中で反応させ、 $\left\{\left[\mathrm{Cd}_{2}(\mathrm{pzdc})\right.\right.$ $\left.\left.{ }_{2} \mathbf{L}\left(\mathrm{H}_{2} \mathrm{O}\right)_{2}\right] \cdot 5\left(\mathrm{H}_{2} \mathrm{O}\right) \cdot\left(\mathrm{CH}_{3} \mathrm{CH}_{2} \mathrm{OH}\right)\right\}_{\mathrm{n}}(\mathrm{CPL}-201)$ を得た。単結

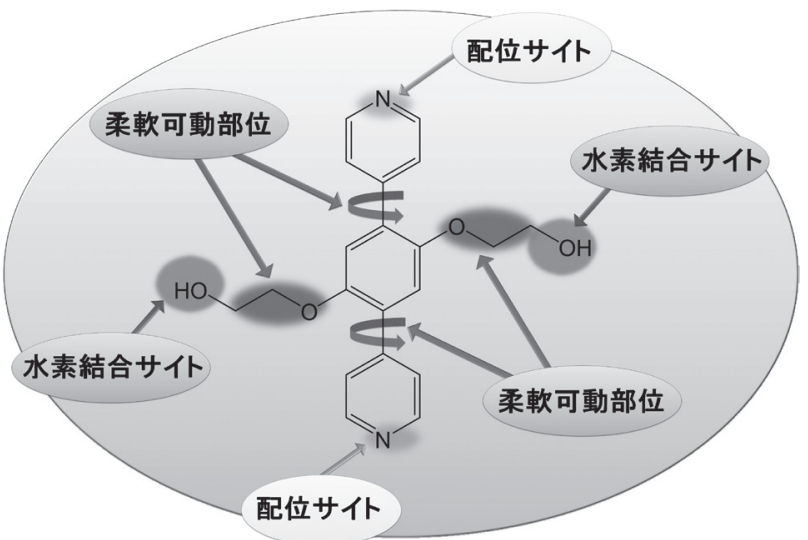

Fig. 8 Schematic drawing of a ligand molecule for CPL-201.

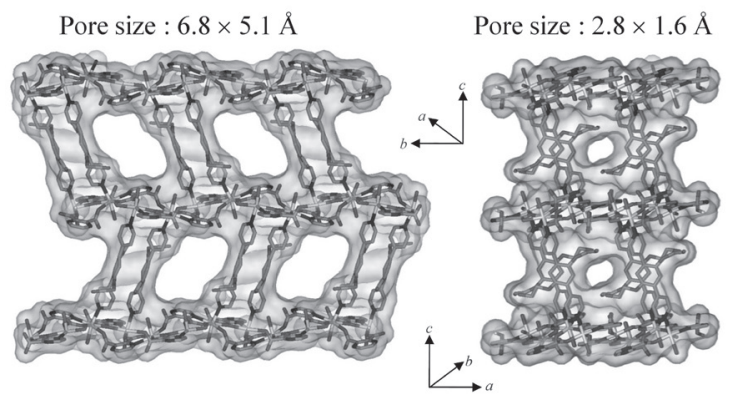

Fig. 9 Crystal structural views of CPL-201. Guest molecules are omitted for clarity.

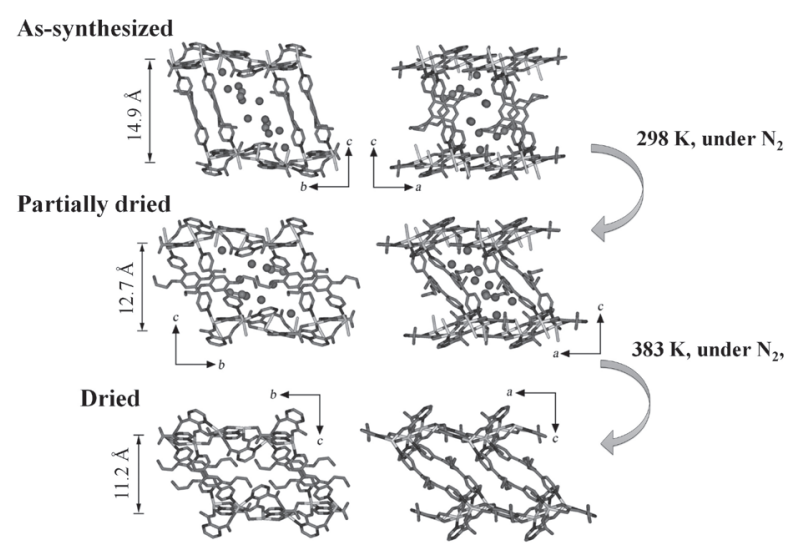

Fig. 10 Structural change of CPL-201 upon drying.

晶構造解析の結果、CPL-201 は CPL-0 シリーズと同様 に金属イオンと pzdc で 2 次元レイヤー状構造を形成し、 その 2 次元シートを配位子 L が連結するピラードレイ ヤー型の構造であった (Fig. 9)。合成時の CPL-201 は約 $7 \times 5 \AA^{2}$ のチャンネル断面をもつ 1 次元細孔を有してお り、チャンネル内部の空間は合成溶媒であるエタノール と水で満たされていた。興味深いことに、CPL-201 は結 晶性を保ったまま段階的に内部のゲスト分子を取り除く ことが可能であり、それぞれの中間状態の結晶構造を決 定することができた (Fig. 10)。合成直後の構造ではレイ ヤー間距離は $14.9 \AA$ であり、中心のベンゼン環の $\pi$ 電 子平面が細孔表面となり（すなわちチャンネル方向へ水 平に配列し）、側鎖はチャンネル方向へ向き、広い細孔 
空間を確保していた。この錯体を $298 \mathrm{~K}$ で窒素雾囲気中 に置くと内部のゲスト分子の一部が抜け、レイヤー間距 離が $12.7 \AA$ に収縮した。また中心のベンゼン環が 90 度 回転して、ゲスト分子が抜けたことによって生じる空隙 を補完していた。この中間状態の結晶をさらに窒素雾 囲気中で $383 \mathrm{~K}$ で加熱すると、細孔に残っていたゲスト 分子のすべてと、Cdイオンに配位していた水分子のす べてがとりのぞかれた。その結果、レイヤー間は $11.2 \AA$ まで収縮するとともに、興味深いことに側鎖の水酸基が 別の隣の側鎖の水酸基と水素結合することによって、側 鎖とベンゼン環が固定され、細孔空間のまったくない非 多孔体へと変化していた。

このように段階的な構造変化を伴う珍しいゲスト脱着 現象を示したことから、逆に CPL-201 の吸着挙動に興 味がもたれた。そこでまずCPL-201 の水の吸着挙動を 調べるために、 $298 \mathrm{~K}$ での水の吸着等温線測定を行った。 その結果、Fig. 11 に示すように 3 段階の吸着を示す等温 線が得られた。等温線中のI、II、III、IVのそれぞれの 点で粉末 $X$ 線回折測定を行い、単結晶 $X$ 線結晶構造解 析の結果との比較を行った結果、次のメカニズムで吸着 が起こっていることがわかった。Iから II の間ではレイ ヤー間距離は変化せず、フレームワークの大きな構造変 化をともなわないで、配位不飽和となっている $\mathrm{Cd}$ サイ トへ水が配位する。続いて II から III の間ではレイヤー
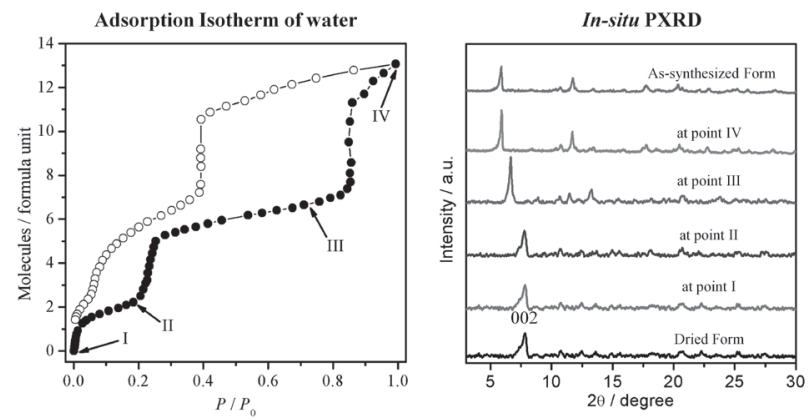

Fig. 11 Adsorption isotherm of water on CPL-201 and variation of in situ PXRD patterns of CPL-201 upon water adsorption.
間を押し広げ細孔空間を形成し、そこへ水分子が吸着さ れる。また、このプロセスで側鎖の 2- ヒドロキシエト キシ基間の水素結合がゲストの水分子によって開裂し、 側鎖とベンゼンの固定が解かれ動的特性が向上した状態 となる。そして III から IV の過程では、レイヤー間が 完全に広がるとともに、ベンゼン環が回転して大きな細 孔空間を獲得し、多くの水分子を取り込む。この変化を 模式的に表すと Fig. 12 のようになり、側鎖はあたかも ベンゼン環で作られるゲートを側鎖間の水素結合でロッ クし、ゲスト分子の細孔への出入りを制御しているかの ように見える。そこでCPL-201に対する他のゲスト分 子の吸着挙動についても検討を行つた。その結果を Fig. 13 に示す。メタノールは水素結合性の分子であるため 予想通り、比較的容易にゲートを開けて吸着されること がわかった。一方、二酸化炭素は高相対圧領域まで吸着
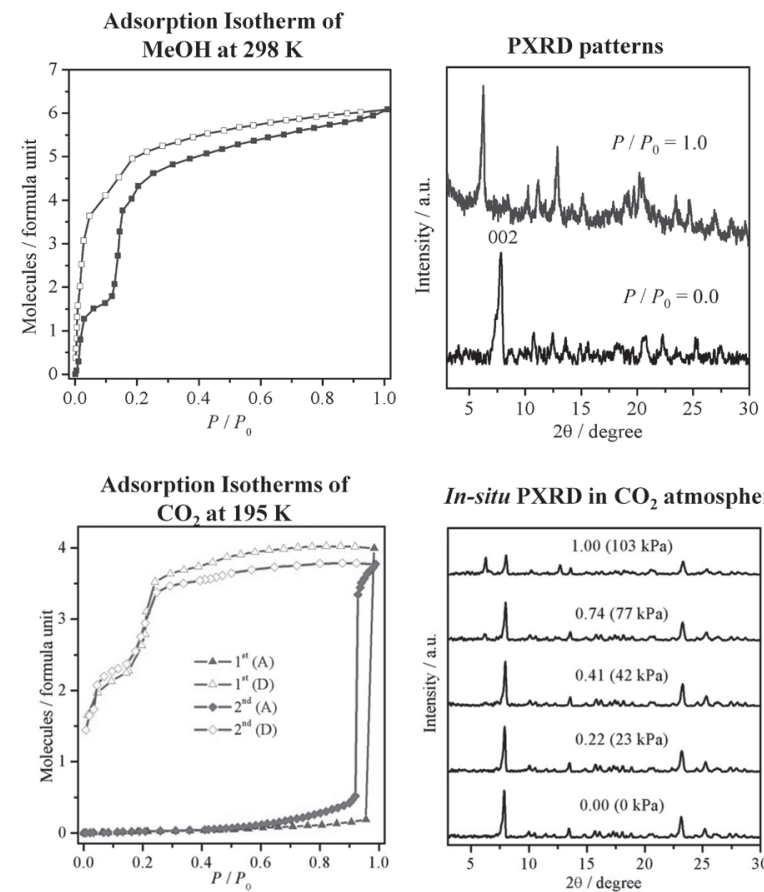

In-situ PXRD in $\mathrm{CO}_{2}$ atmosphere

Fig. 13 Adsorption isotherms and PXRD patterns of methanol (upper) and carbon dioxide (bottom).

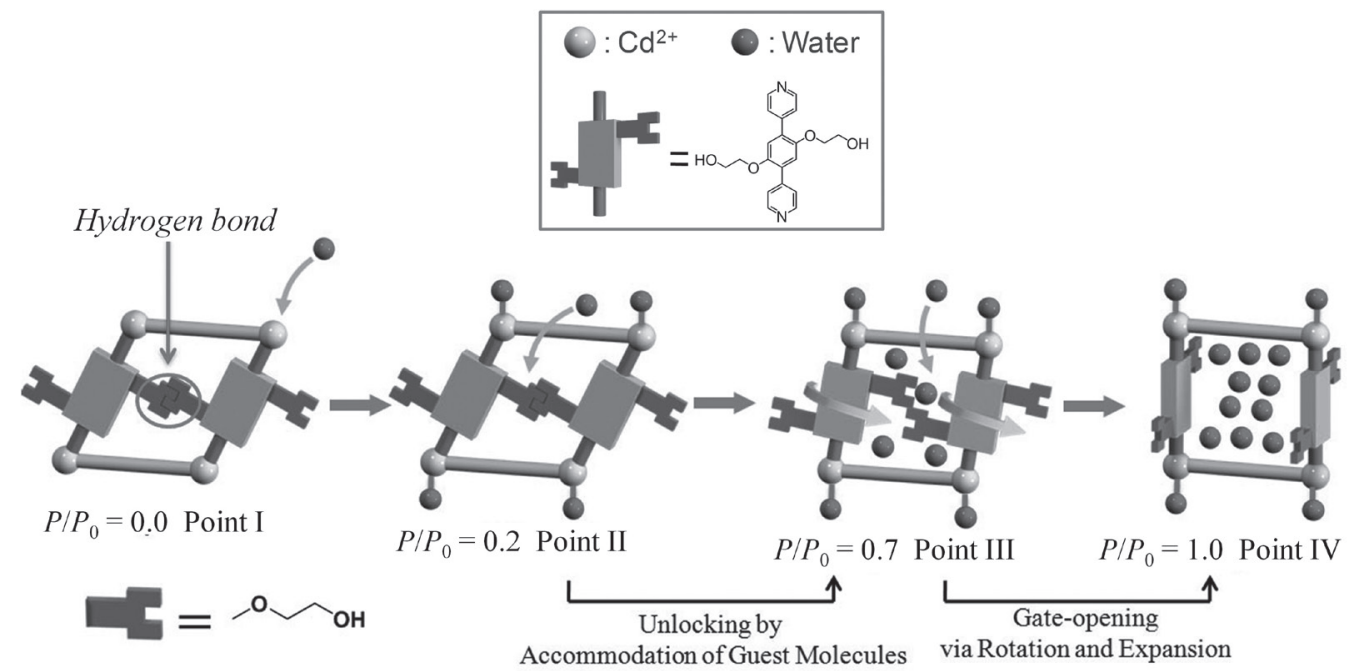

Fig. 12 Schematic drawing of the mechanism for the stepwise water adsorption on CPL-201. 
されないが、相対圧 0.9 付近で急激な構造変化を伴って 吸着が起こった。これは二酸化炭素の水素結合能が非常 に弱く、ゲートを開けることが難しいためであると考え られる。この等温線のように高相対圧で一気に吸着され て、非常に大きなヒステリシスを伴って脱着がおこる吸 着挙動は非常に珍しく、ゲートを有する多孔性配位高分 子で可能になった吸着特性である。

\section{4. 電荷移動相互作用を利用した NO、 $\mathrm{O}_{2}$ の選択 的吸着}

上記のように選択的吸着を実現する 1 つの手法は、ホ ストーゲスト間のある相互作用の大きさが特定のゲスト 分子に対してのみ大きい、あるいは小さいことを見出し、 その相互作用が顕著に吸着挙動に影響する細孔表面を構 築することである。我々は、電子構造を柔軟に変化で きる TCNQ (7,7,8,8-テトラシアノ- $p$-キノジメタン )を 用いて多孔性配位高分子を合成することを考えた ${ }^{122,123)}$ 。 一般に TCNQ は中性状態では電子受容性を示し、2 電子 還元状態では電子供与性を示すことから、TCNQ で作ら れた細孔表面は酸化還元活性なゲスト分子と電荷移動相 互作用することが期待できる ${ }^{51,91,124,125)}$ 。また TCNQ は 4 つのシアノ基を有し、これが配位部位として働くこと によって高次元構造を構築することが可能である。

$\mathrm{Zn}\left(\mathrm{NO}_{3}\right)_{2} \cdot 6 \mathrm{H}_{2} \mathrm{O} 、$ bpy および TCNQ の一電子還元体の 塩である $\left[\mathrm{Li}^{+}(\mathrm{TCNQ})\right]$ をメタノール/ベンゼンの混合溶 液中で反応させると、 $\left\{\left[\mathrm{Zn}(\mathrm{TCNQ})_{2} \mathrm{bpy}\right] \cdot 1.5 \mathrm{C}_{6} \mathrm{H}_{6}\right\}_{n}$ の組成 を有する緑色の結晶（錯体 1) が得られた。結晶構造解 析の結果、反応系中で 2 つ TCNQアニオンが 7 位の 炭素間でシグマ結合を形成し二量化しており、2 価のア ニオン配位子 $\left(\mathrm{TCNQ}_{2}\right)^{2-}$ となっていた。亜鉛は 6 配位 8 面体構造をとり、4つの equatorial 位に $\left(\mathrm{TCNQ}_{2}\right)^{2-}$ が配位 し、2つの axial 位に bpy が配位して、3 次元構造を形成 していた (Fig. 14)。錯体 1 は広い細孔空間が狭い通路で つながつた蛇腹構造を有していた。広い細孔空間には合 成溶媒のベンゼンが 1 分子取り込まれていた。このベン ゼンは TCNQ の $\pi$ 平面がつくる 2 面の壁から $\mathrm{CH}-\pi$ 相
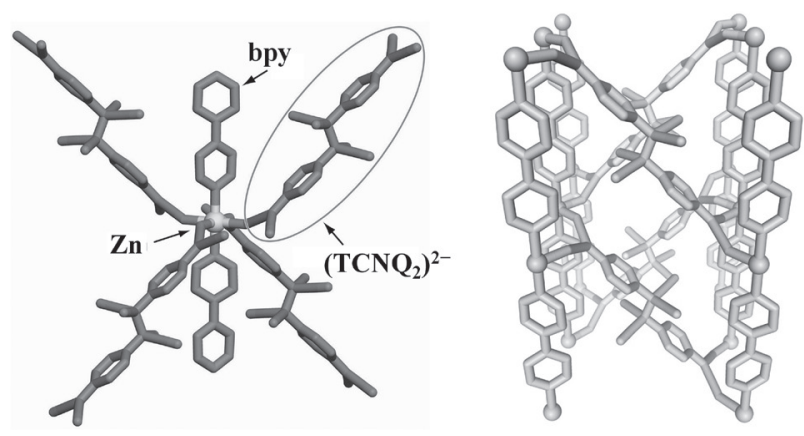

Fig. 14 Crystal structures of complex 1. Views around coordination geometry (left) and of three-dimensional network (right).

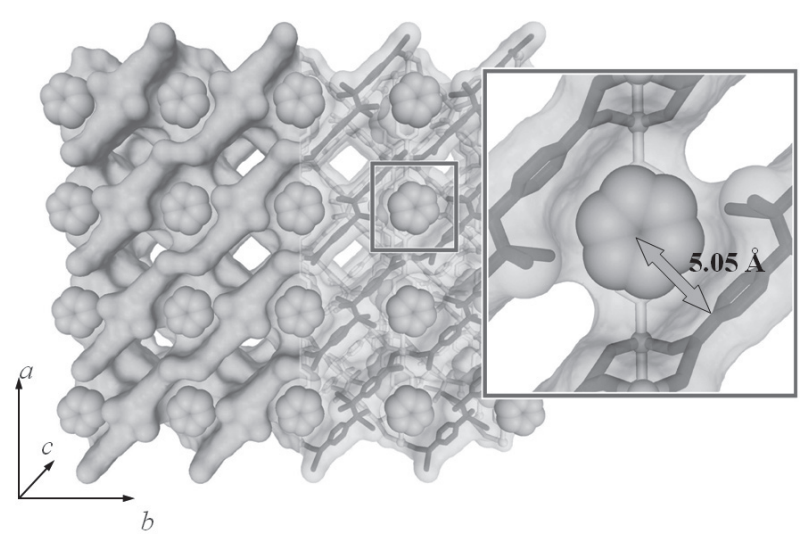

Fig. 15 Crystal structure of as-synthesized complex 1 which accommodates benzene molecules.

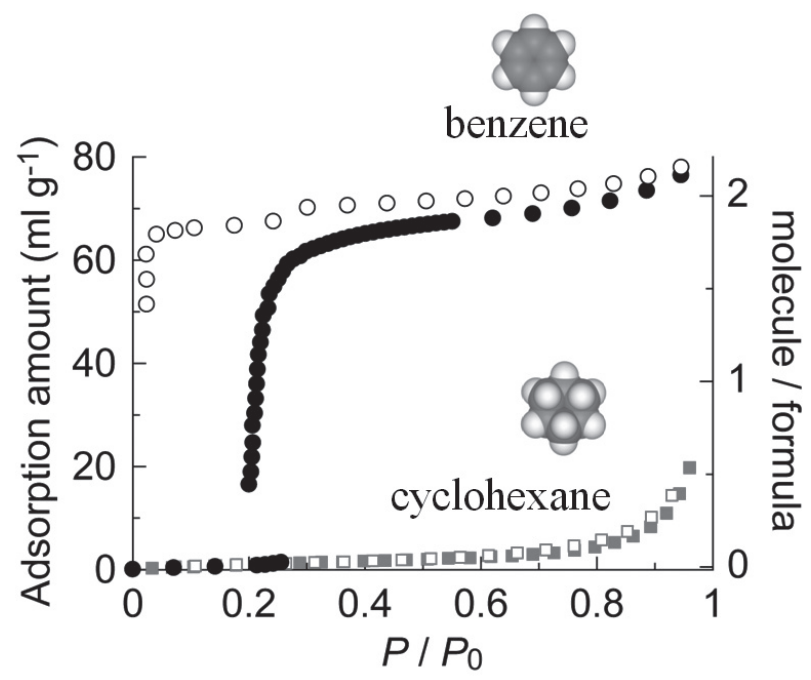

Fig. 16 Adsorption isotherms of benzene and cyclohexane on complex 1 at $298 \mathrm{~K}$.

互作用を介して近距離で相互作用しており、まさにベン ゼンがすっぽりとはまった包摂状態にあった (Fig. 15)。 錯体 1 は加熱真空乾燥することにより、内部のベンゼン を取り除くことが可能であり、その際格子が著しく収縮 することから、蛇腹構造が変形し細孔がかなり縮んだ構 造になっていると考えられる。錯体 1 はベンゼンに対し て強く相互作用できる細孔を元来有していることから、 ベンゼンと同じ炭素数を有し、沸点がほとんど変わらな いシクロヘキサンを対象に（ベンゼンの沸点： $80.10{ }^{\circ} \mathrm{C}$ 、

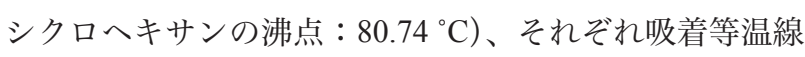
測定を行い、ゲスト選択性について検討を行つた。その 結果、ベンゼンは $20 \mathrm{mmHg}$ 付近の圧力で構造変化を伴 って急激に吸着されるのに対して、シクロヘキサンはま ったく吸着されないということがわかった (Fig. 16)。さ らに、混合溶液を用いた選択的吸着実験においても、非 常に高い選択性でベンゼンを取り込むことがわかった (Fig. 17)。体積比でベンゼン 1 に対してシクロヘキサン 1000 の溶液を調整し、その雾囲気中に錯体 1 を曝した ところ、驚くべきことに錯体内部に取り込まれたゲスト 分子は 97\%がベンゼンであった。 

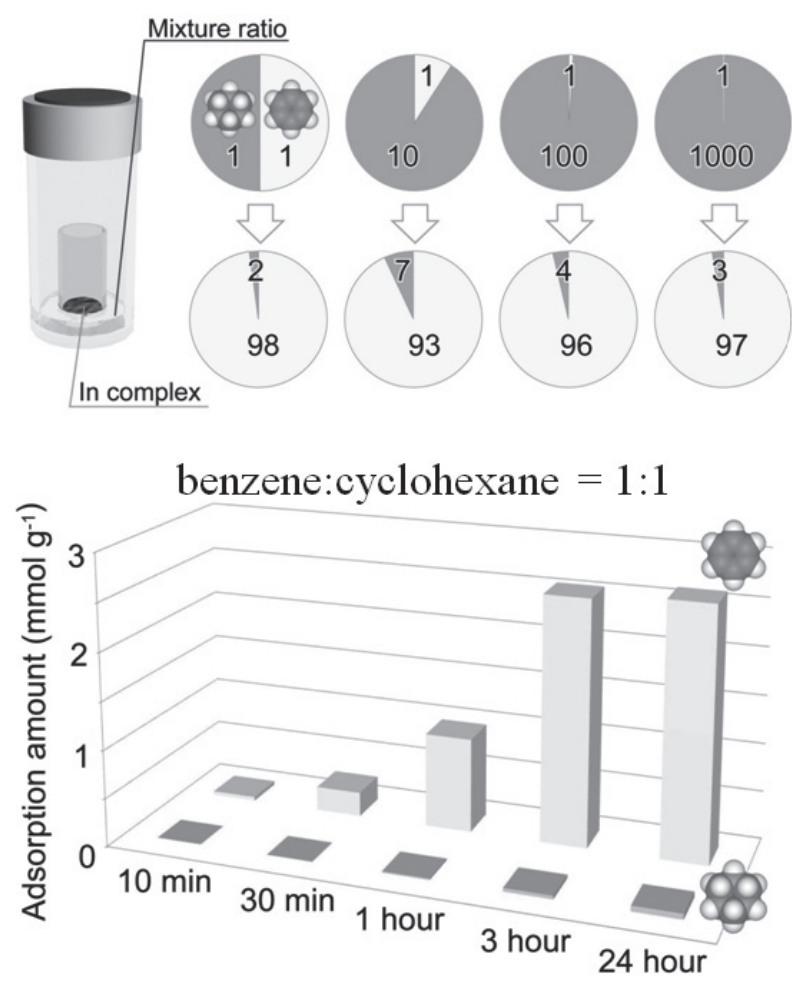

Fig. 17 Guest separation property of complex 1 for benzene and cyclohexane.

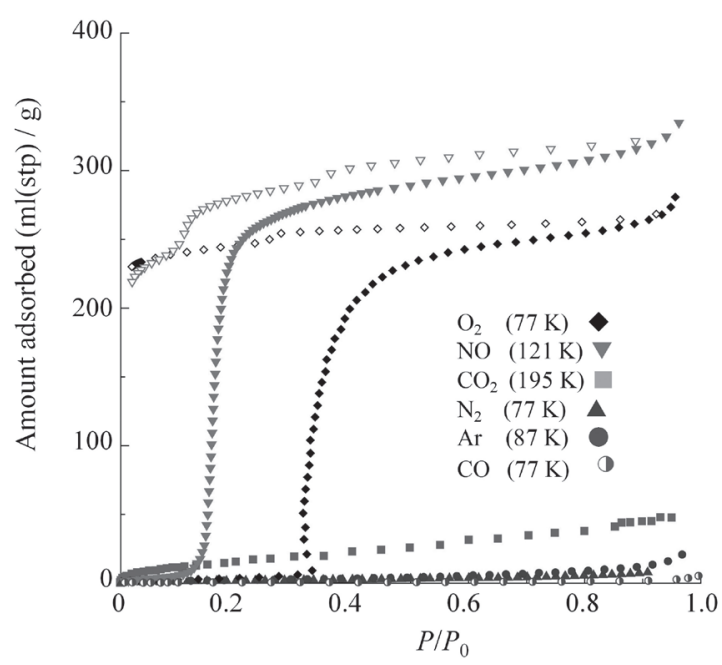

Fig. 18 Adsorption isotherms of various gases on complex 1.

続いて、他のゲスト分子に対する選択性を検討するた めに、様々なガスの吸着等温線測定を行った。その結 果、Fig. 18 に示すように、二酸化炭素、アルゴン、窒 素、一酸化炭素はほとんど錯体 1 に吸着されないのに対 して、一酸化窒素と酸素はゲートオープン型の吸着挙動 を示し、大量に錯体 1 に取り込まれることがわかった。 酸素と一酸化窒素に対して選択的に吸着する例は他にな い。Fig. 1 に示したようにアルゴンと酸素は沸点も分子 サイズも非常に似通っており、アルゴンを吸着せずに酸 素を吸着することは非常に特異な現象である。

この選択性を理解するために、酸素吸着状態におけ る In situの IR および Raman 測定を行った。TCNQ 配位 子の $\mathrm{CN}$ 結合の伸縮振動に由来する吸収は脱ガス構造で
は $2138 \mathrm{~cm}^{-1}$ 及び $2192 \mathrm{~cm}^{-1}$ に観測されたが、酸素を吸 着した状態ではそれらは高波数シフトし $2156 \mathrm{~cm}^{-1}$ 及び $2213 \mathrm{~cm}^{-1}$ に観測された。このことは TCNQがラジカル アニオン状態から、より負電荷が少なくなった電子状態 へ変化し、それに伴って CN の三重結合性が強くなった ことに起因している。一方、Raman 測定によって、酸 素分子の Raman シフト $v(\mathrm{O}=\mathrm{O})$ が $1454 \mathrm{~cm}^{-1}$ に観測され た。これは通常の固体酸素分子の值の $1552 \mathrm{~cm}^{-1}$ から 50 $\mathrm{cm}^{-1}$ ほど低波数シフトしている。酸素の一電子酸化体 の $\mathrm{O}_{2}{ }^{-}$が $1145 \mathrm{~cm}^{-1}$ に観測されることから、吸着された 酸素は部分還元状態にあると考えられる。以上の分光実 験から、錯体 1 に酸素が吸着された状態では、配位子の $\mathrm{TCNQ}^{-}$から酸素分子へ部分的な電子移動が起こってい ると推測できる。なぜ一酸化窒素と酸素の夕選択的に吸 着されるかということについては、ゲスト分子の基底状 態と一電子還元状態のエネルギー差（すなわち一電子還 元による不安定化の度合い）がひとつの指標となること がわかった。酸素および一酸化窒素のそれはそれぞれ 4 および $32 \mathrm{~kJ} / \mathrm{mol}$ であるのに対し、二酸化炭素、アルゴ ン、窒素、一酸化炭素はそれぞれ 351、332、242、186 $\mathrm{kJ} / \mathrm{mol}$ と極端に高くなっている。以上の結果から、一 酸化窒素と酸素は、他の分子と比較して電子受容性が強 く、 $\mathrm{TCNQ}^{-}$でできた電子供与性の細孔表面と部分的な 電子移動が可能なために、このような選択的吸着挙動が 見られたものと考えられる。また、ゲート型の吸着から も示唆されるように、この錯体は吸着に際して大きな構 造変化を伴う。電荷移動相互作用に加えて、構造変化も 選択性の発現に何らかの寄与をしていると考えられる が、今後の検討課題である (Fig. 19)。

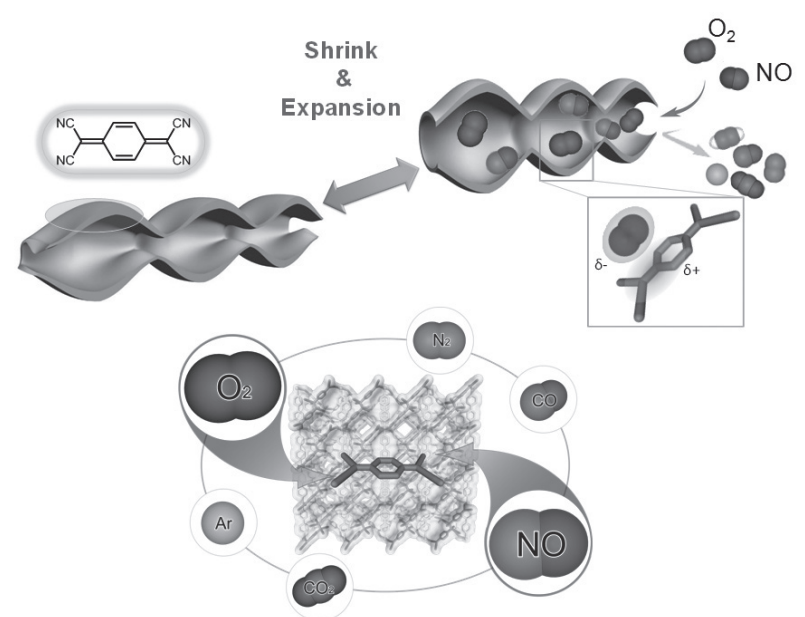

Fig. 19 Schematic drawing of selective adsorption for nitric oxide and oxygen on complex 1 showing flexible structural transformation. 


\section{5. 光応答性多孔性配位高分子〜オンデマンド型 ガス吸着〜}

選択的吸着を実現するためにはビルデイングブロック となる有機配位子や金属イオンの配位状態を工夫し、吸 着活性点を細孔表面へ導入すること ${ }^{34,121,126-131)}$ が重要で あることを述べてきた。しかしながら、選択性をあげる ために有機配位子を高活性にしていくことには限界があ る。通常、多孔性配位高分子は溶液中で、場合によっ ては $100^{\circ} \mathrm{C}$ 以上の高温で合成を行う。このような反応条 件において、有機配位子をあまりに反応活性にしてしま うと、反応系中の溶媒分子や有機配位子、あるいは金属 イオンと副反応を起こし、失活してしまう。その問題を 解決するために、我々は活性種の前駆体となる比較的安 定な配位子を用いて多孔性配位高分子を合成し、後から 外的刺激を加えて細孔を活性化することを考えた (Fig. 20)。この手法により、通常ではフレームワークの合成 中に失活してしまうような活性種を細孔内部に発生させ ることが可能なだけでなく、任意の夕イミングで細孔を 活性化しゲスト分子をトラップしたり、反応させたりす ることが可能となり、まったく新しいオンデマンド型の 多孔性配位高分子を創製できると考えた。前駆体として はアリールアジドを用いることとした。アリールアジド は紫外光を照射することによって、窒素を放出して電子 的に活性な開款構造を有するナイトレンを生成するこ とが知られている ${ }^{132)}$ 。のナイトレンは一酸化炭素や、 酸素分子と速やかに反応して、イソシアナートや二ト 口化合物を与える (Fig. 21) ${ }^{133)}$ 。5- アジドイソフタル酸、 bpy および $\mathrm{Zn}\left(\mathrm{NO}_{3}\right)_{2} \cdot 6 \mathrm{H}_{2} \mathrm{O}$ を DMF / メタノールの混合溶

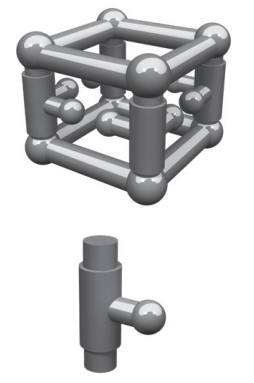

安定前駆体

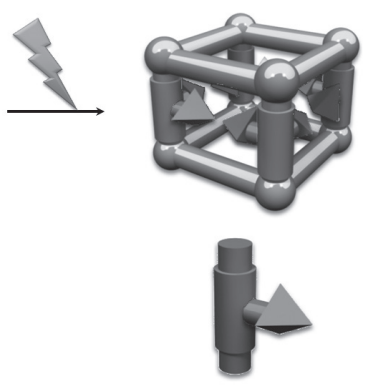

反応活性種
Fig. 20 Schematic drawing of a stimuli-responsive porous coordination polymer.

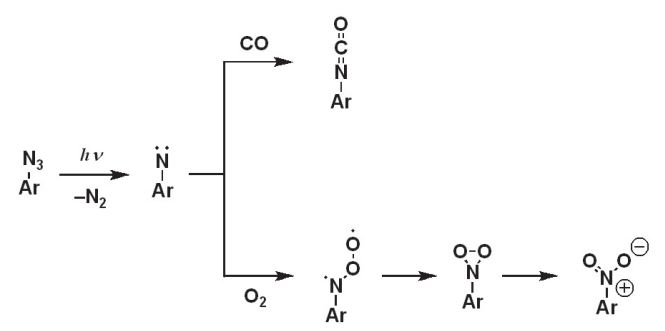

Fig. 21 Reaction properties of nitrene with carbon monoxide and oxygen.

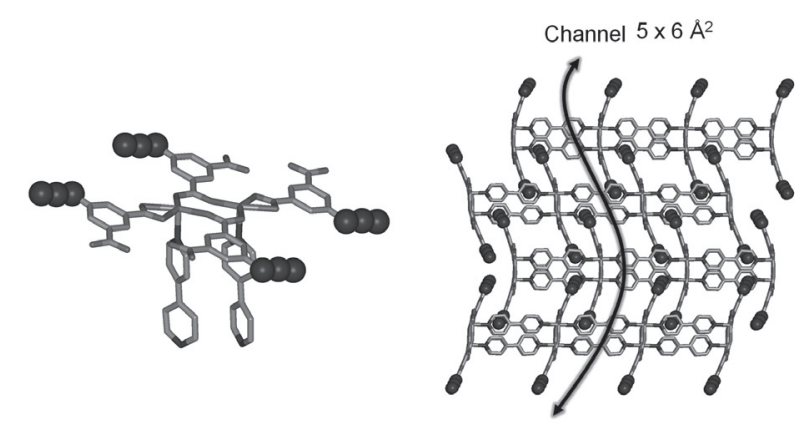

Fig. 22 Crystal structures of CID- $\mathrm{N}_{3}$. Views around coordination geometry (left) and of three-dimensional network (right).

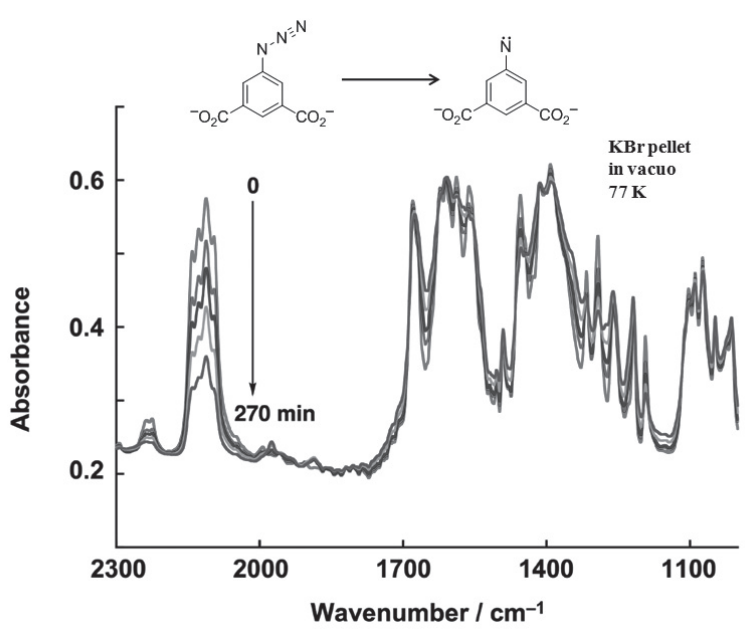

Fig. 23 Variation of IR spectrum of $C I D-N_{3}$ by photoirradiation.

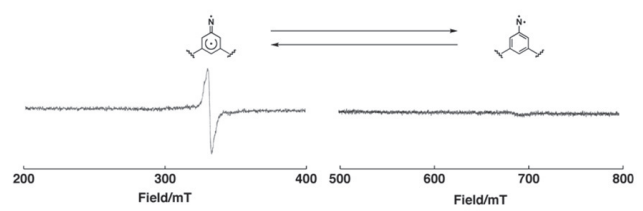

Fig. 24 ESR spectrum of photo-irradiated CID-N ${ }_{3}$. Signal of nitrene (right) and of its biradical form (left)

液中で反応させ、無色の結晶 $\left[\mathrm{Zn}_{2}\left(\mathrm{~N}_{3} \text {-ipa }\right)_{2}(\mathrm{bpy})_{2}(\mathrm{DMF})_{1.5}\right]$ n $\left(\mathrm{CID}-\mathrm{N}_{3}\right)$ を得た。CID- $\mathrm{N}_{3}$ はレイヤーがかみ合ったイン ターディジテイト構造を有しており、レイヤー間に $5 \times$ $6 \AA^{2}$ の細孔断面の一次元チャンネルを有していた (Fig. 22)。アジド部位は細孔表面に露出しており、もし光照 射によってナイトレンを生成することができれば、ゲス 卜分子と特異的に反応することが期待できる構造であ つた。そこで、真空条件下で CID- $\mathrm{N}_{3}$ に紫外光照射を行 い、in situでの IR、ESR および放射光を用いた単結晶 X 線回折測定を行った。IRスペクトルでは光照射に伴い アジド基由来の $2200 \mathrm{~cm}^{-1}$ 付近の吸収が減少し (Fig. 23)、 また ESR スペクトルではナイトレンとその平衡状態に あるビラジカル体のシグナルが観察された (Fig. 24)。さ らに単結晶 $\mathrm{X}$ 線構造解析にも成功し、細孔表面にナイ トレンが発生していることがわかった (Fig. 25)。続いて 酸素を吸着させた状態で光を照射すると、発生したナイ トレンが酸素分子を化学的にトラップできるかどうかの 


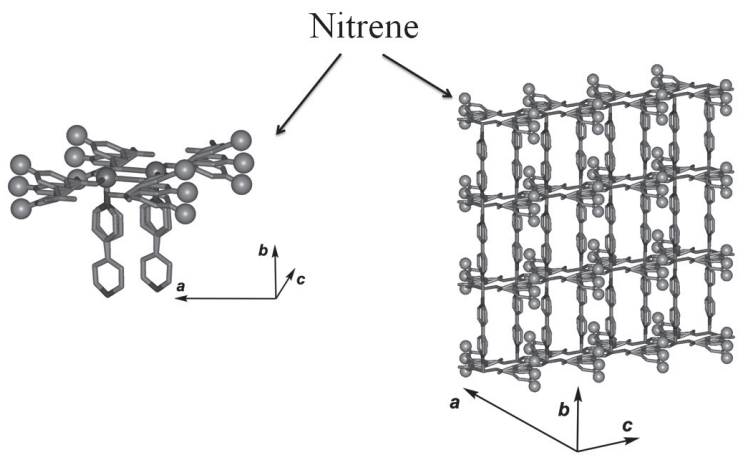

Fig. 25 Crystal structures of photo-irradiated CID-N ${ }_{3}$. Views around coordination geometry (left) and of three-dimensional network (right)

実証を試みた。120 K において CID-N $\mathrm{N}_{3}$ に十分酸素を吸 着させ、その後光照射を行った。In situのIR 測定によ って反応を追跡し、反応が進行しなくなったところでサ ンプルを回収し、塩酸水溶液に溶解させ分析を行った。 その結果、未反応の配位子の他に 2 種類イソフタル酸誘 導体が存在することがわかった。1つは予想通りナイト レンが酸素分子と反応しニトロ基に変換された、5-ニ トロイソフタル酸であった。もう一方は、酸素 1 原子が ナイトレンと結合したニトロソ基を有する 5-ニトロソ イソフタル酸であった。ナイトレンと酸素の反応でニト ロソ化合物を生成し単離した例は非常に珍しく ${ }^{134) 、}$ 制 限されたナノ空間で反応が起こったためであると考えら れる。一酸化炭素に関しても同様の実験をした結果、IR スペクトルの変化から細孔表面のナイトレンは一酸化炭 素をトラップし、イソシアナート基へと変換されること がわかつた (Fig. 26)。

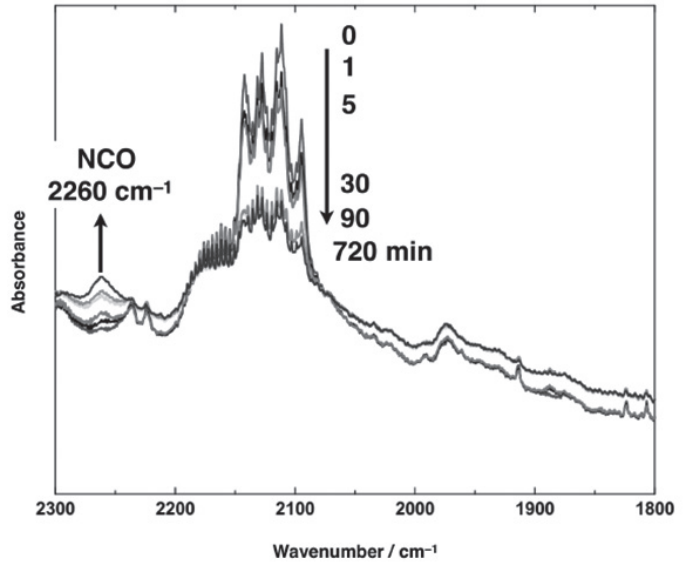

Fig. 26 Variation of IR spectrum of CID- $\mathrm{N}_{3}$ by photoirradiation under $\mathrm{CO}$ atmosphere.

オンデマンド型の吸着を実現するために、光照射を行 いながら吸着測定を行い、光照射が吸着挙動に及ぼす効 果の検討を行った。CID- $\mathrm{N}_{3}$ は $77 \mathrm{~K}$ でほとんど酸素を吸 着しないことがわかっていた。そこで、この条件で光を 照射しながら吸着等温線測定を行ったところ、吸着量の 著しい増加が観測された。In situ で光反応を完全に進行

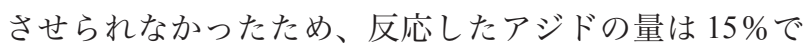
あったが、光反応したサンプルの酸素吸着能を見積もつ たところ、光照射前の CID-N $\mathrm{N}_{3}$ に比べ最大で 29 倍以上 の酸素吸着能があるとわかった (Fig. 27)。この実験から、 ゲスト分子を「光」という外部刺激によって任意にトラ ップし化学変換可能であることを示した (Fig. 28) ${ }^{135)}$ 。

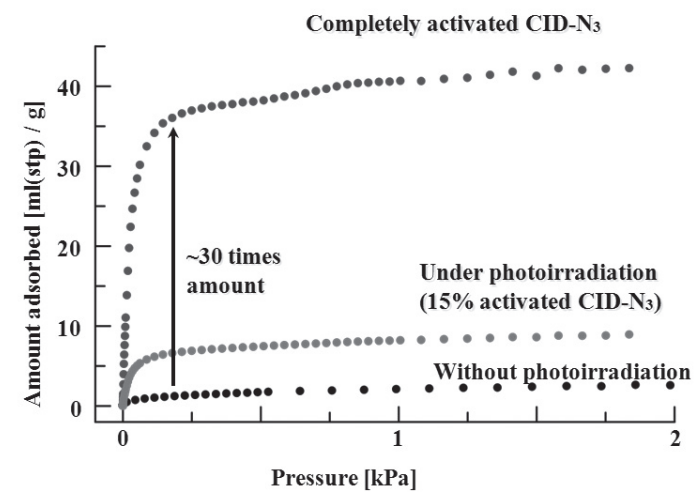

Fig. 27 Adsorption isotherms on CID- $\mathrm{N}_{3}$ without photoirradiation, under photoirradiation, and an estimated isotherm on completely activated CID- $\mathrm{N}_{3}$.

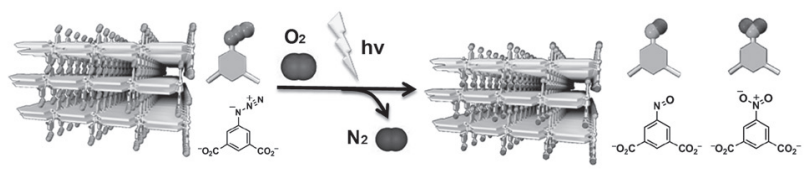

Fig. 28 Schematic representation of on-demand guest trapping and conversion in a porous coordination polymer by photoirradiation.

\section{6. まとめ}

多孔性配位高分子の魅力は物質の多様性にある。新し い有機配位子と金属を組み合わせてできた多孔性配位高 分子は必然的に新物質であり、新しい多孔性機能を有す る可能性を秘めている。吸着等温線はIUPACによって

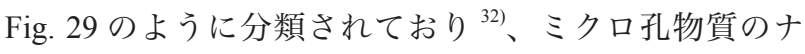
ノ空間への吸着は通常 I 型の等温線を示すことが知られ ている。しかしながら、本論文で示したように、多孔性

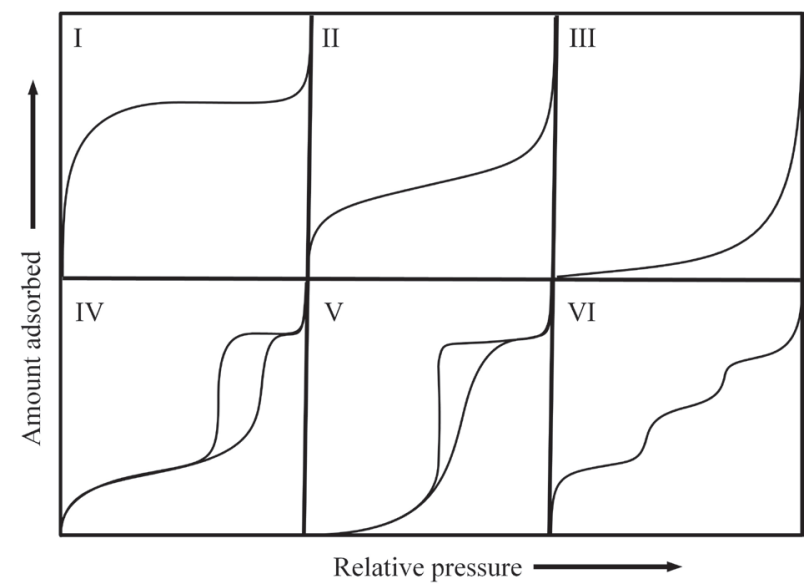

Fig. 29 The IUPAC classification of sorption isotherms. 
配位高分子の中にはミクロ孔を有しながら I 型とはかけ 離れた等温線を示すものも見つかってきており、従来材 料ではみられなかった特異な選択的吸着を示すものを合 成できることがわかってきた。その一方で、特異な吸着 現象の基礎的な理解はあまり進んでいない。今後はさら に新しい多孔性配位高分子の開発を進めると共に、なぜ 多孔性配位高分子が特異な吸着をするのかという基礎的 理解を深め、錯体としての多孔性物質である多孔性配位 高分子の新しい展開を行っていきたい。

\section{7. 謝辞}

本研究を行うにあたり、ご指導とご支援いただきまし た北川進教授 (京都大学) に深謝いたします。本研究は 京都大学の学生および JST ・ ERATO 研究員諸氏、また 多くの共同研究者の方々の協力を得て行ったものです。 特に下村悟博士（京都大学）、坂本裕俊博士（信州大学）、 Seo Joobeom 博士 (JST)、佐藤弘志博士 (JST)、高坂亘 博士 (JST)、Bonneau Charlotte 博士 (JST)、Bureekaew Sareeya 博士（Ruhr Univ., Germany）には大きく貢献し ていただきました。共同研究者の高田昌樹グループディ レクター (理化学研究所)、北浦良准教授 (名古屋大学)、 久保田佳基准教授 (大阪府立大学)、小林達生教授（岡 山大学)、杉本邦久博士 (JASRI)、樋口雅一助教（京都 大学)、Tapas K. Maji 准教授 (JNSCR, India)の多大なご 支援の無しには本研究を行うことはできませんでした。 心より感謝申し上げます。また、本研究を遂行するにあ たりまして、ご助言いただきました佐藤治教授（九州大 学)、大場正昭教授 (九州大学)、張浩徹准教授 (北海道 大学)、および京都大学北川研究室、JST ・ ERATO 北川 統合細孔プロジェクトの皆様に厚く御礼申し上げます。

\section{文献}

1) IUPAC Manual of Symbols and Terminology, appendix 2,. Part 1, Colloid and Surface Chemistry, Pure Appl. Chem., 31, 578 (1972).

2) F. Schüth, K. S. W. Sing and J. Weitkamp, Handbook of Porous Solids, volume 1, WILEY-VCH, Weinheim, (2002).

3) D. W. Breck, Zeolite Molecular Sieves, Wiley \& Sons, New York, (1984).

4) S. Kitagawa and R. Matsuda, Coord. Chem. Rev. 251, 2490 (2007).

5) D. Bradshaw, J. B. Claridge, E. J. Cussen, T. J. Prior and M. J. Rosseinsky, Acc. Chem. Res., 38, 273 (2005).

6) G. Férey, C. Mellot-Draznieks, C. Serre and F. Millange, Acc. Chem. Res., 38, 217 (2005).

7) F. Schüth, K. S. W. Sing and J. Weitkamp, Handbook of Porous Solids, volume 2, WILEY-VCH, Weinheim, (2002).

8) O. M. Yaghi, M. O'Keeffe, N. W. Ockwig, H. K. Chae, M. Eddaoudi and J. Kim, Nature, 423, 705 (2003).

9) D. Bradshaw, T. J. Prior, E. J. Cussen, J. B. Claridge and M. J. Rosseinsky, J. Am. Chem. Soc., 126, 6106 (2004).
10) M. Eddaoudi, D. B. Moler, H. Li, B. Chen, T. M. Reineke, M. O'Keeffe and O. M. Yaghi, Acc. Chem. Res., 34, 319 (2001).

11) S. Kitagawa, R. Kitaura and S. Noro, Angew. Chem., Int. Ed., 43, 2334 (2004)

12) C. Janiak, Angew. Chem., Int. Ed., 36, 1431 (1997).

13) S. R. Batten and R. Robson, Angew. Chem., Int. Ed., 37, 1460 (1998).

14) A. J. Blake, N. R. Champness, P. Hubberstey, W.-S. Li, M. A. Withersby and M. Schröer, Coord. Chem. Rev., 183, 117 (1999).

15) O. R. Evans and W. Lin, Acc. Chem. Res., 35, 511 (2002).

16) I. Goldberg, Chem. Eur. J,. 6, 3863 (2000).

17) P. J. Hagrman, D. Hagrman and J. Zubieta, Angew. Chem., Int. Ed. 38, 2638 (1999).

18) A. N. Khlobystov, A. J. Blake, N. R. Champness, D. A. Lemenovskii, A. G. Majouga, N. V. Zyk and M. Schröder, Coord. Chem. Rev., 222, 155 (2001).

19) K. Kim, Chem. Soc. Rev., 31, 96 (2002).

20) S. Kitagawa and M. Munakata, Trends Inorg. Chem., 3, 437 (1993).

21) S. Kitagawa and M. Kondo, Bull. Chem. Soc. Jpn., 71, 1739 (1998).

22) S. Kitagawa and R. Kitaura, Comments Inorg. Chem., 23, 101 (2002).

23) S. Kitagawa and S. Kawata, Coord. Chem. Rev, 224, 11 (2002).

24) B. Moulton and M. J. Zaworotko, Chem. Rev., 101, 1629 (2001).

25) M. Munakata, Adv. Inorg. Chem., 46, 173 (1998).

26) H. Okawa and M. Ohba, Bull. Chem. Soc. Jpn., 75, 1191 (2002).

27) O. M. Yaghi, H. Li, C. Davis, D. Richardson and T. L. Groy, Acc. Chem. Res., 31, 474 (1998).

28) M. J. Zaworotko, Chem. Soc. Rev., 283 (1994).

29) M. J. Zaworotko, Chem. Commun., 1 (2001).

30) C. Janiak, Dalton Transactions, 2781 (2003).

31) Q. Li, W. Zhang, O. S. Miljanic, C.-H. Sue, Y.-L. Zhao, L. Liu, C. B. Knobler, J. F. Stoddart and O. M. Yaghi, Science, 325, 855 (2009).

32) F. Rouquerol, J. Rouquerol and K. Sing, Adsorption by Powders and Porous Solids, Academic Press, London, (1999).

33) K. Kaneko, R. F. Cracknell and D. Nicholson, Langmuir, 10, 4606 (1994).

34) J. S. Seo, D. Whang, H. Lee, S. I. Jun, J. Oh, Y. J. Jeon and K. Kim, Nature, 404, 982 (2000).

35) M. Kondo, T. Okubo, A. Asami, S. Noro, T. Yoshitomi, S. Kitagawa, T. Ishii, H. Matsuzaka and K. Seki, Angew. Chem., Int. Ed., 38, 140 (1999).

36) R. Kitaura, K. Fujimoto, S. Noro, M. Kondo and S. Kitagawa, Angew. Chem., Int. Ed., 41, 133 (2002).

37) R. Kitaura, S. Kitagawa, Y. Kubota, T. C. Kobayashi, K. Kindo, Y. Mita, A. Matsuo, M. Kobayashi, H.-C. Chang, T. C. Ozawa, M. Suzuki, M. Sakata and M. Takata, Science, 298, 2358 (2002).

38) R. Kitaura, R. Matsuda, Y. Kubota, S. Kitagawa, M. Takata, T. C. Kobayashi and M. Suzuki, J. Phys. Chem. B, 109, 23378 (2005).

39) R. Matsuda, R. Kitaura, S. Kitagawa, Y. Kubota, T. C. Kobayashi, S. Horike and M. Takata, J. Am. Chem. Soc., 126, 14063 (2004).

40) R. Matsuda, R. Kitaura, S. Kitagawa, Y. Kubota, R. V. Belosludov, T. C. Kobayashi, H. Sakamoto, T. Chiba, M. Takata, Y. Kawazoe and Y. Mita, Nature, 436, 238 (2005).

41) Y. Kubota, M. Takata, R. Matsuda, R. Kitaura, S. Kitagawa and T. C. Kobayashi, Angew. Chem., Int. Ed., 45, 4932 (2006).

42) Y. Kubota, M. Takata, R. Matsuda, R. Kitaura, S. Kitagawa, K. Kato, M. Sakata and T. C. Kobayashi, Angew. Chem., Int. Ed., 44, 
920 (2005)

43) D. Li and K. Kaneko, J. Phys. Chem. B, 104, 8940 (2000).

44) T. Uemura, S. Horike and S. Kitagawa, Chem. Asian J., 1, 36 (2006).

45) T. Uemura, R. Kitaura, Y. Ohta, M. Nagaoka and S. Kitagawa, Angew. Chem., Int. Ed., 45, 4112 (2006).

46) R. Radhakrishnan, K. E. Gubbins and M. Sliwinska-Bartkowiak, $J$. Chem. Phys., 112, 11048 (2000).

47) S. Budavari, THE MERCK INDEX TEWLFTH EDITION, Merck Research Laboratories, New Jrsey, (1996).

48) D. N. Dybtsev, H. Chun and K. Kim, Angew. Chem., Int. Ed., 43, 5033 (2004).

49) D. Tanaka, S. Masaoka, S. Horike, S. Furukawa, M. Mizuno, K. Endo and S. Kitagawa, Angew. Chem., Int. Ed., 45, 4628 (2006).

50) O. Ohmori, M. Kawano and M. Fujita, J. Am. Chem. Soc., 126, 16292 (2004).

51) H. J. Choi and M. P. Suh, J. Am. Chem. Soc., 126, 15844 (2004).

52) J. L. C. Rowsell, E. C. Spencer, J. Eckert, J. A. K. Howard and O. M. Yaghi, Science, 309, 1350 (2005).

53) G. J. Halder and C. J. Kepert, J. Am. Chem. Soc., 127, 7891 (2005).

54) T. K. Maji, G. Mostafa, R. Matsuda and S. Kitagawa, J. Am. Chem. Soc., 127, 17152 (2005).

55) M. R. Hartman, V. K. Peterson, Y. Liu, S. S. Kaye and J. R. Long, Chem. Mater., 18, 3221 (2006).

56) S. Takamizawa, T. Saito, T. Akatsuka and E. Nakata, Inorg. Chem., 44, 1421 (2005).

57) S. Takamizawa, E. Nakata, T. Saito and T. Akatsuka, Inorg. Chem., 44, 1362 (2005).

58) S. Takamizawa and E. Nakata, CrystEngComm, 7, 476 (2005).

59) S. Takamizawa, E. Nakata and T. Saito, Angew. Chem., Int. Ed., 43, 1368 (2004).

60) S. Takamizawa, E. Nakata, H. Yokoyama, K. Mochizuki and W. Mori, Angew. Chem., Int. Ed., 42, 4331 (2003).

61) E. Nishibori, M. Takata, K. Kato, M. Sakata, Y. Kubota, S. Aoyagi, Y. Kuroiwa, M. Yamakata and N. Ikeda, J. Phys. Chem. Solid, 62, 2095 (2001).

62) M. Takata, E. Nishibori and M. Sakata, Z. Kristallogr., 216, 71 (2001).

63) H. M. Rietveld, J. Appl. Cryst., 2, 65 (1969).

64) H. K. Chae, D. Y. Siberio-Perez, J. Kim, Y. Go, M. Eddaoudi, A. J. Matzger, M. O'Keeffe and O. M. Yaghi, Nature, 427, 523 (2004).

65) X. Zhao, B. Xiao, A. J. Fletcher, K. M. Thomas, D. Bradshaw and M. J. Rosseinsky, Science, 306, 1012 (2004).

66) M. Eddaoudi, J. Kim, N. Rosi, D. Vodak, J. Wachter, M. O'Keeffe and O. M. Yaghi, Science, 295, 469 (2002).

67) G. Férey, M. Latroche, C. Serre, F. Millange, T. Loiseau and A. Percheron-Guegan, Chem. Commun., 2976 (2003).

68) K. Seki and W. Mori, J. Phys. Chem. B, 106, 1380 (2002).

69) M. Kondo, T. Yoshitomi, K. Seki, H. Matsuzaka and S. Kitagawa, Angew. Chem., Int. Ed., 36, 1725 (1997).

70) M. Kondo, M. Shimamura, S. Noro, S. Minakoshi, A. Asami, K. Seki and S. Kitagawa, Chem. Mater, 12, 1288 (2000).

71) H. Li, M. Eddaoudi, M. O'Keeffe and O. M. Yaghi, Nature, 402, 276 (1999).

72) K. Seki, S. Takamizawa and W. Mori, Chem. Lett., 332 (2001).

73) K. Seki, S. Takamizawa and W. Mori, Chem. Lett., 122 (2001).

74) K. Seki, Phys. Chem. Chem. Phys., 4, 1968 (2002).

75) K. Seki, Chem. Commun., 1496 (2001).

76) S. S.-Y. Chui, S. M.-F. Lo, J. P. H. Charmant, A. G. Orpen and I.
D. Williams, Science, 283, 1148 (1999).

77) L. C. Tabares, J. A. R. Navarro and J. M. Salas, J. Am. Chem. Soc., 123, 383 (2001).

78) D. V. Soldatov and J. A. Ripmeester, Chem. Mater., 12, 1827 (2000).

79) M. Eddaoudi, H. Li and O. M. Yaghi, J. Am. Chem. Soc., 122, 1391 (2000).

80) W. Mori, H. Hoshino, Y. Nishimoto and S. Takamizawa, Chem. Lett., 331 (1999).

81) P. M. Forster, J. Eckert, J.-S. Chang, S.-E. Park, G. Férey and A. K. Cheetham, J. Am. Chem. Soc., 125, 1309 (2003).

82) M. Fujita, J. Y. Kwon, S. Washizu and K. Ogura, J. Am. Chem. Soc., 116, 1151 (1994).

83) R. Tannenbaum, Chem. Mater, 6, 550 (1994).

84) B. Gomez-Lor, E. Gutierrez-Puebla, M. Iglesias, M. A. Monge, C. Ruiz-Valero and N. Snejko, Inorg. Chem., 41, 2429 (2002).

85) J. M. Tanski and P. T. Wolczanski, Inorg. Chem., 40, 2026 (2001).

86) O. R. Evans, H. L. Ngo and W. Lin, J. Am. Chem. Soc., 123, 10395 (2001).

87) M. Dincă and J. R. Long, J. Am. Chem. Soc., 127, 9376 (2005).

88) S. S. Kaye and J. R. Long, J. Am. Chem. Soc., 127, 6506 (2005).

89) K. Uemura, K. Saito, S. Kitagawa and H. Kita, J. Am. Chem. Soc., 128, 16122 (2006).

90) K. Yamada, H. Tanaka, S. Yagishita, K. Adachi, T. Uemura, S. Kitagawa and S. Kawata, Inorg. Chem., 45, 4322 (2006).

91) S. Shimomura, R. Matsuda, T. Tsujino, T. Kawamura and S. Kitagawa, J. Am. Chem. Soc., 128, 16416 (2006).

92) M. Dincă, A. Dailly, Y. Liu, C. M. Brown, D. A. Neumann and J. R. Long, J. Am. Chem. Soc., 128, 16876 (2006).

93) M. Dincă, A. F. Yu and J. R. Long, J. Am. Chem. Soc., 128, 8904 (2006).

94) R. Kitaura, K. Seki, G. Akiyama and S. Kitagawa, Angew. Chem., Int. Ed., 42, 428 (2003).

95) K. Biradha and M. Fujita, Angew. Chem., Int. Ed., 41, 3392 (2002).

96) L. G. Beauvais, M. P. Shores and J. R. Long, J. Am. Chem. Soc., 122, 2763 (2000).

97) K. Biradha, Y. Hongo and M. Fujita, Angew. Chem., Int. Ed., 41, 3395 (2002)

98) M. P. Suh, J. W. Ko and H. J. Choi, J. Am. Chem. Soc., 124, 10976 (2002).

99) C. J. Kepert, D. Hesek, P. D. Beer and M. J. Rosseinsky, Angew. Chem., Int. Ed., 37, 3158 (1998).

100) D. V. Soldatov, J. A. Ripmeester, S. I. Shergina, I. E. Sokolov, A. S. Zanina, S. A. Gromilov and Y. A. Dyadin, J. Am. Chem. Soc., 121, 4179 (1999).

101) J. Y. Lu and A. M. Babb, Chem. Commun., 1340 (2002).

102) B. F. Abrahams, P. A. Jackson and R. Robson, Angew. Chem., Int. Ed., 37, 2656 (1998).

103) A. J. Fletcher, E. J. Cussen, T. J. Prior, M. J. Rosseinsky, C. J. Kepert and K. M. Thomas, J. Am. Chem. Soc., 123, 10001 (2001).

104) C. J. Kepert and M. J. Rosseinsky, Chem. Commun., 375 (1999).

105) S. K. Makinen, N. J. Melcer, M. Parvez and G. K. H. Shimizu, Chem. Eur. J., 7, 5176 (2001).

106) J.-H. Liao, S.-H. Cheng and C.-T. Su, Inorg. Chem. Commun., 5, 761 (2002).

107) K. Barthelet, J. Marrot, D. Riou and G. Férey, Angew. Chem., Int. $E d ., 41,281$ (2002).

108) C. Serre, F. Millange, C. Thouvenot, M. Nogues, G. Marsolier, D. Louer and G. Férey, J. Am. Chem. Soc., 124, 13519 (2002).

109) T. K. Maji, K. Uemura, H.-C. Chang, R. Matsuda and S. Kitagawa, 
Angew. Chem., Int. Ed., 43, 3269 (2004).

110) E. J. Cussen, J. B. Claridge, M. J. Rosseinsky and C. J. Kepert, J. Am. Chem. Soc., 124, 9574 (2002).

111) E. Y. Lee, S. Y. Jang and M. P. Suh, J. Am. Chem. Soc., 127, 6374 (2005).

112) H. Kim and M. P. Suh, Inorg. Chem., 44, 810 (2005).

113) S. Noro, S. Horike, D. Tanaka, S. Kitagawa, T. Akutagawa and T. Nakamura, Inorg. Chem., 45, 9290 (2006).

114) S. Horike, R. Matsuda, D. Tanaka, S. Matsubara, M. Mizuno, K. Endo and S. Kitagawa, Angew. Chem., Int. Ed., 45, 7226 (2006).

115) P. L. Llewellyn, S. Bourrrelly, C. Serre, Y. Filinchuk and G. Férey, Angew. Chem., Int. Ed., 45, 7751 (2006).

116) C. Mellot-Draznieks, C. Serre, S. Surble, N. Audebrand and G. Férey, J. Am. Chem. Soc., 127, 16273 (2005).

117) S. Noro, R. Kitaura, M. Kondo, S. Kitagawa, T. Ishii, H. Matsuzaka and M. Yamashita, J. Am. Chem. Soc., 124, 2568 (2002).

118) S. Noro and S. Kitagawa, Stud. Sur. Sci. Cat., 141, 363 (2002).

119) K. Uemura, S. Kitagawa, M. Kondo, K. Fukui, R. Kitaura, H.-C. Chang and T. Mizutani, Chem., Eur., J., 8, 3586 (2002).

120) J. Gonzalez, R. Nandini Devi, D. P. Tunstall, P. A. Cox and P. A. Wright, Micro. Meso. Mater., 84, 97 (2005).

121) J. Seo, R. Matsuda, H. Sakamoto, C. Bonneau and S. Kitagawa, J. Am. Chem. Soc., 131, 12792 (2009).

122) S. Shimomura, S. Horike, R. Matsuda and S. Kitagawa, J. Am. Chem. Soc., 129, 10990 (2007).
123) S. Shimomura, M. Higuchi, R. Matsuda, K. Yoneda, Y. Hijikata, Y. Kubota, Y. Mita, J. Kim, M. Takata and S. Kitagawa, Nat. Chem., 2, 633 (2010).

124) M. P. Suh, H. R. Moon, E. Y. Lee and S. Y. Jang, J. Am. Chem. Soc., 128, 4710 (2006).

125) H. R. Moon, J. H. Kim and M. P. Suh, Angew. Chem., Int. Ed., 45, 1261 (2005)

126) S. Yang, X. Lin, A. J. Blake, G. S. Walker, P. Hubberstey, N. R. Champness and M. Schroeder, Nat. Chem., 1, 487 (2009).

127) K. L. Mulfort and J. T. Hupp, J. Am. Chem. Soc., 129, 9604 (2007).

128) G. J. Halder, C. J. Kepert, B. Moubaraki, K. S. Murray and J. D. Cashion, Science, 298, 1762 (2002).

129) M. Dincă and J. R. Long, J J. Am. Chem. Soc., 129, 11172 (2007).

130) Y.-G. Lee, H. R. Moon, Y. E. Cheon and M. P. Suh, Angew. Chem., Int. Ed., 47, 7741 (2008).

131) Z. Wang and S. M. Cohen, Chem. Soc. Rev., 38, 1315 (2009).

132) N. P. Gritsan and M. S. Platz, Chem. Rev., 106, 3844 (2006).

133) H. Inui, M. Irisawa and S. Oishi, Chem. Lett., 34, 478 (2005).

134) T. Harder, P. Wessig, J. Bendig and R. Stoesser, J. Am. Chem. Soc., 121, 6580 (1999).

135) H. Sato, R. Matsuda, K. Sugimoto, M. Takata and S. Kitagawa, Nat. Mater., 9, 661 (2010).

\section{Profile}

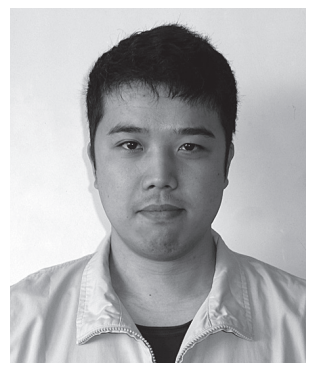

\section{松田 亮太郎}

科学技術振興機構北川統合細孔プロジェクト・グループリーダー/京都大学物質一細胞統合 システム拠点・特任准教授 博士 (工学)

[ 経歴 ] 2000 年京都大学工学部卒業、2005 年京都大学大学院工学研究科博士課程認定退学、 同年京都大学博士研究員、2006 年九州大学先導物質化学研究所助手、2007 年同助教、2008 年より現職。

[専門] 錯体化学、吸着化学、固体化学 